\title{
Impact of Armed Conflict on Economy and Tourism: A Study of State of Jammu and Kashmir.
}

\author{
Ajaz ul Islam ${ }^{1}$ \\ ${ }^{1}$.Ajaz ul Islam, Research Scholar, School of Business, Shri Mata Vaishno Devi University, Sub post office \\ SMVD University, $J \& K$ (India).
}

\begin{abstract}
During the last two and half decades Jammu and Kashmir has been under the political turmoil. During the turmoil hundreds and thousands of precious lives have been wasted. When we look into the circumstances in Jammu and Kashmir it is not only the precious lives that has been lost, other segments of the state also received a considerable down fall. In this study we have tried to identify the impact of this armed conflict on the economic growth in Jammu and Kashmir region with special reference to tourism sector. The specific objective of the study is to get the inferences about the impact of armed conflict on: (i) the overall Economy of Jammu and Kashmir (ii) tourism sector in Jammu and Kashmir.The study was conducted in two stages. In the first stage we have identified the relationship between the growth in the armed conflict and growth in economy of the state. Number of fatalities every year due to armed conflict has been taken as proxy for the growth in armed conflict and NSDP has been taken as the indicator of the economic growth. In the second stage the relationship between number of fatalities and tourist count has been identified. Thestudy finds a significant negative relationship between the growth in the armed conflict and economic growth of the Jammu and Kashmir. Also a significant negative relationship between the armed conflict and economy of the state was found to be occurring. Results revealed that with every unit increase in the armed conflict (which in this case is number of fatalities) decreases the NSDP by .065 units (unit is Rs in Billions). Also when we tried to identify the relationship between the armed conflict and tourism a very significant negative correlation between the two variables was found to be existing (correlation=-.65). While analyzing the impact of armed conflict on the tourist count of the state it was found to be having very high impact. The regression results imply that with every one unit increase in the armed conflict there is a decline of .232 units in the tourist count here unit of tourist count is in thousands). Thus supports the results which were interpreted by the graphical representation. Implications of the study are also discussed.
\end{abstract}

\section{Introduction.}

Kashmir is a stunning and captivating land that abounds with natural beauty. Adorned by snow-capped mountains, wildflower meadows, immense glaciers, and sparkling lakes, Kashmir has often been compared to heaven on earth. However, this pristine image of Kashmir has been replaced by a much more frightening one. India and Pakistan both claim ownership of Kashmir and this dispute has resulted in two major wars as well as thousands of deaths, human rights violations, and atrocious acts of aggression. The conditions of violence in Kashmir are beyond the minds of people. Suicide bombings, attacks by militant groups and open fire by security forces are the main reasons for hostility. Civilians are killed on a daily basis. Every year, there are countless reported cases of torture, rape, deaths in custody, extrajudicial executions, and disappearances. Indiscriminate violence has marked the area since 1989. During the turmoil it is not only the expensive and valuable lives that have been lost but it has also affected theeconomic condition of Kashmir very badly. Reluctance of businessmen to set up business and decline in the number of tourist count has very drastically affected the economy of the Jammu and Kashmir. During the Pre-militancy era the favorite destination was the beautiful Kashmir valley, but with the eruption of violence the tourist lands were deserted and also the people who used to visit Shri Mata Vaishno Devi shrine and Amarnath also diminished. From last few years jammu and kashmir has witnessed increase in number of the tourists to Vaishno Devi shrine, in Jammu region and to Leh in Ladakh Though the number of tourists to Srinagar has increased with the launch of the peace process, their specific targeting by the militants have led to decline in their numbers. The local people bemoan this tragedy befalling on them. In Kashmireconomy has been completely shattered due to ongoing turmoil. While earlier thousands of outsiders thronged to the city, now only hundreds visit the valley. The count of the tourists has fallen from millions in 1980,s to thousands during the peak of the turmoil. Violence has also directly affected other important sources of livelihood such as agriculture, horticulture, and the handicraft industry. These sectors have become the survival mechanisms for the local people but are not flourishing. The state is known for wide variety of agricultural and horticulture products. However, the conflict environment has prevented people from maximally utilizing this gift of the nature. The horticulture industry has also suffered directly as well as indirectly due to conflict situation. These issues are discussed in detail in the section on challenges and 
opportunities. In this study we have tried to identify the impact of the turmoil on the overall economy of the state of Jammu and Kashmir and also on the tourism sector. We found a significant relationship between the change in the armed conflict and the economy and tourist count of the state.

\section{Literature Review}

Since ancient times, Jammu \& Kashmir was among the most popular travel destinations of India due to its natural beauty and being "a seat of great learning" (Mohammad, 2006, p.42). However, with the increase of violence the number of tourists dramatically decreased which caused serious problems for the locals who heavily depended on the revenues of tourism. When we look from the psychological point of view of the decision making process of travelers, the decline of tourist arrivals is a logical consequence of rising terrorist activities since people choose their holiday destination according to the most benefits and least costs, i.e. risks (Sonmez\& Graefe, 1998) whereby a destination with frequent terrorist attacks are usually perceived as high cost.

The Kashmir dispute has always been seen as a fight for freedom and the right of self determination by Pakistan who "pledged moral, political, and diplomatic support to the Kashmir cause" which also "included material support to the fighters of Kashmir" (Akhtar, 2007). Contrarily India perceives the Kashmir issue as a matter of terrorism in the first place and accuses Pakistan to be at fault by "sponsoring and supporting crossborder terrorism" (Akther, 2007,). Moreover the occurrence of 9/11 gave India the opportunity to involve the Kashmir issue in the current War on Terrorism and "to draw maximum benefit from the changed international opinion in favor of fighting terrorism lock stock and barrel" (Akther 2007). Most of the top scholars believed that the Kashmir conflict which is always perceived as a religious conflict is basically not a religious conflict but a political one. It is only to give it a shape of terrorism it has been framed into that situation. As we can easily draw conclusions from the above mentioned statements and there is a great amount of studies (Poland 1988; Toman 1991; Schmid \& Jongman 1988 cited in Sönmez \& Graefe 1998) that support the argument that the actual definition of terrorism cannot be used in the case of Jammu and Kashmir. So taking the context further the impact of the conflict has not only taken the thousand and lakhs of lives it has also frozen the economic development of the state. The state which is very rich in all the natural resources and other things is lagging very much on their economic front. The main reason is the economic conflict. So in this study we have tried to identify the impact of armed conflict on the economy of state of Jammu and Kashmir and also on the tourism sector.

\subsection{Impact of armed conflict on the Economy of Jammu and Kashmir}

Terrorism imposes significant economic effects on societies and will not only lead to direct material damage, but also to long term effects on the local economy. The identification and the estimation of these economic effects of terrorism have received broad attention in economic literature and research during the last few decades. Primary economic impact of terrorism "refers to the effects arising from the immediate aftermath of a terrorist event". These effects include the physical destruction of urban objects, and the human casualties (injuries and losses of human life). There is a direct relationship between the armed conflict and economy of the state. Armed conflict has led to decline in handicraft business, agricultural production and tourism count, especially in the late 1980's (Mahapatra, 2007). Even basic infrastructure like power supply, roads, communication systems and drinking water remain poor because resources are diverted to counter-terrorism activities (Mahapatra, 2007). Likewise silviculture is not possible anymore since Kashmir's forests have become the perfect hiding place for terrorists. Inevitably there is a clear connection between terrorism and increasing unemployment as well. Statistics have shown that the employment rate declined from 44.3 percent in 1981 to 36.6 percent in 2001. Considering that the government is almost the only employer (due to the lack of private investments), that fact is not really surprising. Another very important cost of violence is the waste of human talent" and "loss of creativity that has stunted development and has forced people to think only of survival not of progress (Mahapatra, 2007). Quality of education has suffered dramatically since schools and universities are often closed or even come under fire because of terrorism related activities (Jarudi, 2002). What remains are thousands of low level educated students with no hope for a job driving them to enter into terror groups. Thousands of local boys turned to militant training across the border. The basic cause is not ideological or the jihad factor. Most went because they have nothing here. No future. No job. No hope. If they had hope, they would not go" (Jarudi, 2002). Thisevolution gave the aggrieved party the opportunity to demonstrate their displeasure against the government, however, those who perceived a slight chance to find employment elsewhere and had sufficient funds to leave Kashmir migrated to different parts of India (Ahmad \& Hussain, 2011). As a matter of fact, Jammu \& Kashmir's economic growth could not keep up with the national level (Ahmad \& Hussain, 2011) and can exhibit only 5.27 percent annual growth during the first three years of the tenth five year plan in comparison to the national average of 6.6 percent (Finance \& Planning Commission, 2007). Similarly, "in 2007, the per capita income of the state is only two-thirds of the national average in India" 
(Finance \& Planning Commission, 2007). The economic cost of the conflict cannot be confined to a particular sector of industry or investment prospect, but it had affected the important sources of livelihood of local people such as tourism, horticulture and handicraft industries also (Ahmad \&Hussain, 2011). Nevertheless, terrorism and violence are not the only cause for Jammu \& Kashmir's economic depression but "poor policy management, corruption and lack of infrastructure" as well (Mohapatra, 2007). So in this study we will identify how much terrorism has impact on the economy of the state.

\subsection{Impact on armed conflict on the tourism of Jammu and Kashmir}

Tourism which was thought to be the backbone of Jammu and Kashmir has been drastically affected by the evolution of the armed conflict. The state which was the favored situation of the tourists till 90's has been deserted of the tourists for a very long time. Terrorism often causes cancellations and withdrawal of travel plans to certain destinations; though indicate the tourism industry as extremely indestructible (Chauhan \& Khanna, 2009). The negative news by most of the international and national news channels makes it unthinkable to the people around the world to visit Jammu and Kashmir, because the way they present the news makes jammu and kashmir the terrorist paradise (Buckley and Klemm, 1993). Further it is suggested that locals and foreigners are equally likely to be involved in a crime scenario which causes the crucial variable "fear of the unknown and the risk" (Chauhan \& Khanna, 2009). The news channels and reports play a very important role, the way they make situation worse in Jammu and Kashmir no one else has contributed to that. They make the dead bodies speculative in their news channels like they are showing some sort of miraculous objects not keeping in view the psychological effects they have on people. (Ashraf, 2008). In order to avoid "this intentional or unintentional damage to the travel business in Jammu \& Kashmir, and to keep a positive image alive media and officers of the travel industry must cooperate and closely work together. In addition, the local tourism industry could try to implement common marketing strategies such as incentive airline tickets or hotel rate discounts (Sonmez \& Graefe, 1998) to promote the destination and to limit the impact of militancy on this sector.In an attempt to gain a deeper inside view into the special relationship between terrorism and tourism many studies proposed that tourists (and sometimes also important sights) might be the perfect victim for terrorism since they are sensed as representatives of their countries and therefore cause a much higher media coverage and international attention. Consequentially, the involvement of the concerned countries of origin increases pressure on the actual targeted government and the worldwide publishing of the militants' opinions makes travellers the best channel for militants to get the messages and demands across (Richter, 1983). In this regard also the attack on the tourist is perceived as attack on the government that is why tourists are sometimes attacked to show their anger against the government (Ryan, 1993). In Jammu and Kashmir many such incidents have also taken place where the people from the resistance have attacked the local and foreign tourists. So in this study we will also try to identify the impact of armed conflict on the tourism of the state.

\subsection{Data source and sample size.}

\section{Research methodologies}

The data has been collected from the secondary sources. The economic condition of the state is represented by the NSDP. The data for NSDP has been collected from RBI website which provides state wise data. And the data regarding the number of tourists who have visited Jammu and Kashmir is collected from the $\mathrm{JK}$ tourism website. The data for number of fatalities due to the armed conflict has been collected from the south Asian war Statistics report. The data has been collected from year 1988 to 2012. The data for all the three variables has been collected for 25 years from the time the conflict has started and to 2012 .

\subsection{Statistical methods and development of model.}

First of all the graphical representation to make comparison between the percentage change in number of fatalities and the change in NSDP and the percentage change in tourist count.Then a correlation analysis has been carried to identify the degree of relatedness between the variables. Also the same procedure has been repeated for the tourist count and NSDP. We have used simple linear regression model to identify the impact of armed conflict on the economic performance of the state. Another regression equation gives us Impact of armed conflict on the tourist count. The two equations can be written as

$$
\begin{array}{lll} 
& Y_{1}=\alpha+\beta X+\mu & \text { eq. (1) } \\
& Y_{2}=\alpha+\beta X+\mu & \text { eq. (2) } \\
\text { - } & Y 1=\text { NSDP for different years } \\
\text { - } \quad Y 2=\text { tourist count for different years } \\
\text { - } \quad \mathrm{X}=\text { number of fatalities due to armed conflict fore different years } \\
\text { - } \quad \alpha, \beta=\text { parameters } \\
\text { - } \mu=\text { error term }
\end{array}
$$

Here: 
So by this model we will be able to identify the impact of armed conflict on the economy and tourism of Jammu and Kashmir.

\section{Results}

The results of the study can be interpreted in two different steps (1) first we will identify the impact of the armed conflict on the economy of the state of Jammu and kashmir (2) alsostudy tries identify the impact of armed conflict on the tourism of Jammu and Kashmir.

\subsection{Impact of the armed conflict on the economy of the state;}

In the second section of the study we are trying to identify the impact of armed conflict on the NSDP of the state of Jammu and Kashmir. We have first of all plotted a graph between the changes in to NSDP andchange in the fatalities due to armed conflict, and then we have identified the cause and relationship analysis between the two variables using the simple linear regression model.

While analyzing the impact of armed conflict on the economy of the state from the graphical representation is becomes clear that there is a negative relationship between the armed conflict and the economy of the state of Jammu and Kashmir. From the fallowing graph the situation becomes clearer.

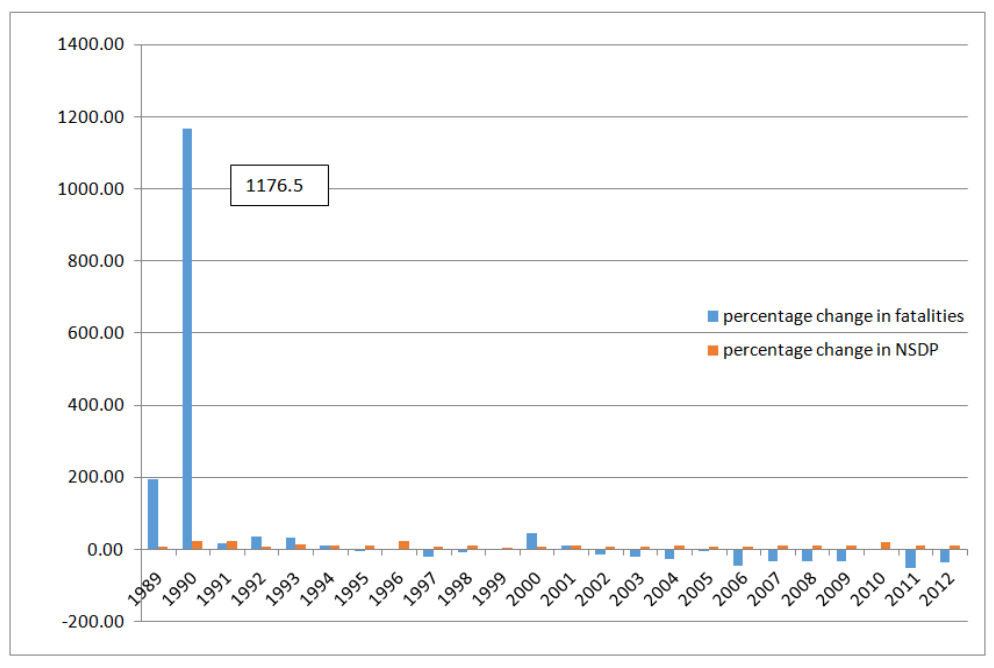

As we can clearly see from the graph that for the years where there is high increase in the percentage of fatalities the growth in the economy is very decent and vice versa. The graph makes it clear that relationship between the twovariables is opposite to each other, there is a negative correlation of -.476 which means with the increase in one other is going to decrease. Also we can also identify from the graph still the economy is not recovering because of economic stability and economy is not recovering to the extant it should have recovered with decline in the percentage of the fatalities. The reason being the perception of the people, because they think the situation in Kashmir is highly volatile and it can change its face anytime. So most of people are reluctant to invest their money in Jammu and Kashmir and also the tourists have still in mind and they are not ready to risk their lives.

Now to identify the extent to which the armed conflict has affected the overall tourism count a regression is being run between the two variables to identify the extent of the impact.

Here:

$$
\mathrm{Y}_{1}=\alpha+\beta \mathrm{X}+\mu
$$

$\mathrm{Y}_{1}=$ NSDP of the state per year

$\mathrm{X}=$ number of fatalities due to armed conflict per year

$\alpha, \beta=$ parameters

$\mu=$ error term

The regression model of the equation also comes up with the significant results. The model has been tested for the different assumptions. The impact of armed conflict on the economy of the state will be highlighted from the fallowing estimatedregression equation using OLS regression model. The fitness of the model was calculated through $\mathrm{R}^{2}$ and the value of $\mathrm{R}^{2}$ was found to be 0.67 which means model explains $67 \%$ of the change in one variable with respect to the other. 


$$
\mathrm{Y}_{1}=317.29-0.065 \mathrm{X}
$$

The estimated equation provides us information that with every $1 \%$ increase in the violence that means with every percent increase in the violence there will be $.065 \%$ decrease in the NSDP of the Jammu and Kashmir state. The result was found to be significant at $5 \%$ level of significance. This means there is a very significant impact on the economy of Jammu and Kashmir by this armed conflict.

\subsection{Impact of the armed conflict on the Tourism count of the state.}

In the second section of the study we are trying to identify the impact of armed conflict on the tourism of the state of Jammu and Kashmir. We have first of all plotted a graph between the tourism count andnumber of fatalities due to armed conflict, and then we have identified the cause and relationship analysis between the two variables using linear regression.

The fallowing graph clearly shows a negative relationship between the two variables as with positive change to the number of conflicts it is drastically reducing the tourist count as we can clearly see from the graph. While we have identified the correlation between the two there were found to be negatively correlated. A negative correlation of -0.64 was found between the two variables which is very high value. As tourism has been found to be one of the most important sectors of Jammu and Kashmir economy, the decline is this sector has drastically affected the overall economy of the state.

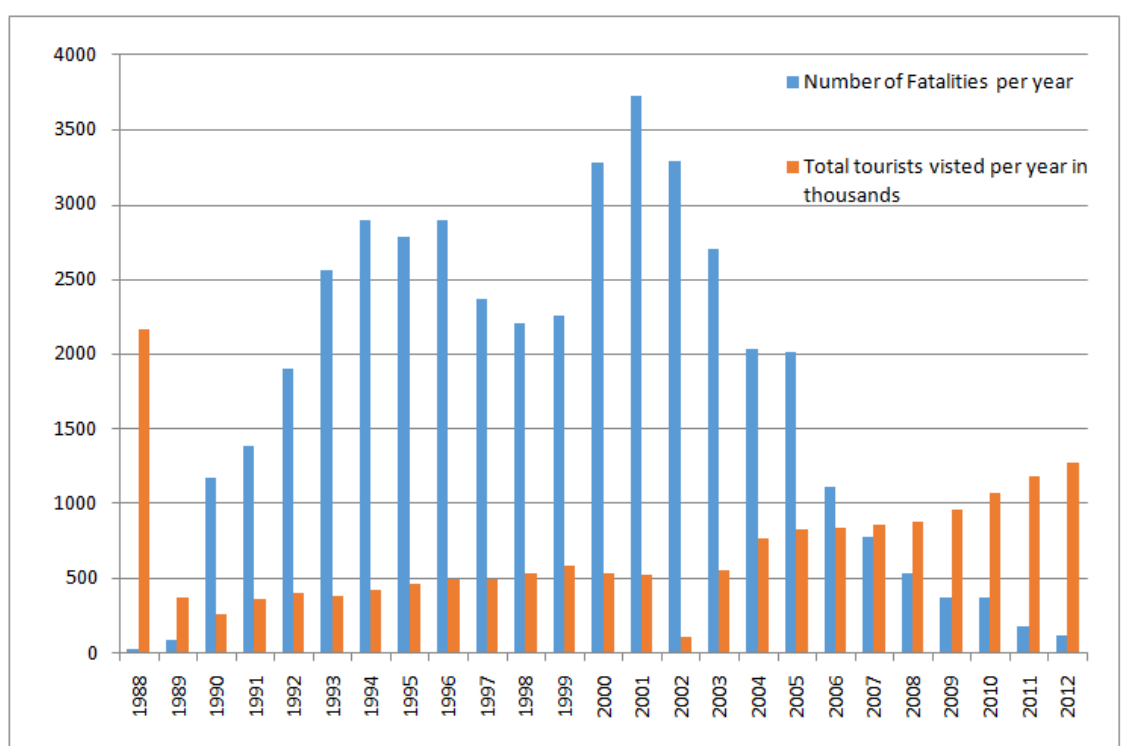

Now to identify the extent to which the armed conflict has affected the overall tourism count a regression is being run between the two variables to identify the extent of the impact.

Here:

$$
\mathrm{Y}_{2}=\alpha+\beta \mathrm{X}+\mu
$$

$\mathrm{Y} 2=$ tourist count for different years

$\mathrm{X}=$ number of fatalities due to armed conflict fore different years

$\alpha, \beta=$ parameters

$\mu=$ error term

When the regression was run between the two variables the results were found to be statistically significant at $1 \%$ level of significance. The model has been tested for the different assumptions. The impact of armed conflict on the economy of the state will be highlighted from the fallowing estimatedregression equation using OLS regression model. The fitness of the model was calculated through $\mathrm{R}^{2}$ and the value of $\mathrm{R}^{2}$ was found to be 0.64 which means model explains $64 \%$ of the change in one variable with respect to the other. So the final estimated regression model will be

$\mathrm{Y}_{2}=1096.076+-.232 \mathrm{X}+\mu$

The fallowing model suggests that with every $1 \%$ change in the number of fatalities there is a negative change of .232\%. This has also been shown by the graphclearly which shows a negative correlation between the two. So from these results we have found that tourism is very heavily affected by the armed conflict and also we have quantified the impact of every unit increase in the conflict. 


\section{Conclusion and implications}

In this study we have tried to identify the impact of armed conflict on the economy and tourism of state of Jammu and Kashmir. The armed conflict has not only taken the precious lives but also it has shaken the economy of the state from its roots. The armed conflict has very severely affected the economy as well as the tourism sector which was the backbone of the economy of the state. So in this study we have tried to identify to what extent the armed conflict has an impact on the economy of the state. So to identify this we have taken data of last 25 years right from the time when the conflict started of three important variables which include NSDP of the state, Number of Fatalities per year and Tourism Count per year. First of all we have used NSDP as to measure the overall economy of the state and number of fatalities as proxy for the condition of the armed conflict. Also the number of tourist count of last 25 years has been collected from the website of ministry of tourism. So the three main variables were major elements of the study. First we have tried to identify the impact of armed conflict on the economy of state and it has been clearly found that there is a negative impact on the economy of state by the armed conflict and the cause and effect relationship was found using linear regression model. It was found that with every unit increase in the armed conflict (which in this case is number of fatalities) decreases the NSDP by .065 units (unit is Rs in Billions). Also when we tried to identify the relationship between the armed conflict and tourism of the state we have found a very significant negative correlation between the two. A negative correlation of 0.65 was found to be present between the two variables. While analyzing the impact of armed conflict on the tourist count of the state it was found to be having very high impact. The regression results imply that with every one unit increase in the armed conflict there is a decline of .232 units in the tourist count (here unit of tourist count is in thousands). Thus supports the results which were interpreted by the graphical representation.

The implication of the study is very broad. It can be used as government to make better provisions to tackle these issues of armed conflict and form new policies and rules. It can also be used to make people aware about what they have lost during previous 25 years so that they think of a better future without the armed conflict. This will also give a message to the other parts of the world about the economic effects of the armed conflict. This will also encourage the researcher to work on this topic and particularly on the state of Jammu and Kashmir and identify various other aspects of conflict.

In conclusion, the state of Jammu and Kashmir has really suffered a huge loss due to the armed conflict from the last 25 years and this thing must be made clear that the conflict is not going to help the state any way nor it is going to help the India which is spending a huge chunk of its defense budget only in kashmir. So a better mutual solution should come out so that the state of Jammu and Kashmir can flourish in near future.

\section{Limitations of the study}

The study has been conducted for whole state of Jammu and Kashmir but when we look at the condition of Jammu and Kashmir we understand that armed conflict is mostly confined to the Kashmir province only. Also we have taken overall economic condition into consideration we can also look into different sectors like tourism industrial growth etc. Further study can make an elaborativedifferentiation between the effects on the three provinces of Jammu and Kashmir to make it more specific.

\section{References}

[1]. Ahmad, I. M. \& Hussain, N. A. (2011): 'Impact of Turmoil on Tourism of Kashmir.' Journal of Economics and Sustainable Development 2(7), pp.1-7

[2]. Akhtar, S. (2007): 'War on Terrorism \& Kashmir Issue.' Research Fellow, Institute of Regional Studies, pp. 1-9.

[3]. Arunatilake, A. et.aI. (1999), The Economic Cost of the War in Sri Lanka, Institute of Policy Studies, Colombo.

[4]. Ashraf, F. (2002): 'Jammu and Kashmir Dispute: Examining Various Proposals for its Resolution.'Published by The Institute of Strategic Studies in Islamabad, Series: Islamabad Papers (20), pp. 1-51

[5]. Chaudhary, P. (2002): 'Religious Terrorism - The Latest Threat (Juxtaposition of Jammu's Heritage -Living and Vibrant versus Dead and Decaying.' Strategies for the World's Cultural Heritage. Preservation in a globalized world: principles, practices and perspectives. 13th ICOMOS General Assembly and Scientific Symposium, Madrid, pp. 311-314

[6]. Chauhan, V. \& Khanna, S. (2009): 'Tourism: A Tool for Crafting Peace Process in Kashmir, J\&K, India.' Tourismos: An International Multidisciplinary Journal of Tourism 4(2), pp. 69-89

[7]. Cockburn, C. (1999), Gender, Armed Conflict and Political Violence, Background Paper Presented at the World Bank Conference on Gender, Armed Conflict and Political Violence, June 10-11, World Bank, Washington, D.C.

[8]. Dr. Mahapatra, D. (2007): 'Conflict and Development in Kashmir: Challenges and opportunities.' Proceedings of the International Conference on Sustainable Development in Conflict Environments, Kathmandu: Centre for International Studies and Cooperation, pp. 68-77.

[9]. Dr. Soundararajan, R. \& Major Rajan, M. (2006): 'Impact of Terrorism on Jammu and Kashmir Tourism.' Delhi: Kalpaz Publications

[10]. Sönmetz, S. F. \& Graefe, A. R. (1998): 'Influence of Terrorism Risk on Foreign Tourism Decisions.' Annals of Tourism Research 25(1), pp. 112-144

[11]. Jarudi, I. (2002): 'The People of Kashmir.' MURJ 6(21), pp. 21-24

[12]. Sönmetz, S. F. \& Graefe, A. R. (1998): 'Influence of Terrorism Risk on Foreign Tourism Decisions.' Annals of Tourism Research 25(1), pp. 112-144

[13]. Woods J., Ten Eyck T. A., Kaplowitz S. A., Shlapentokh V. (2008): 'Terrorism Risk Perception to Primary Terrorist Targets: How Close is Too Close?' Human Ecology Review 15(1), pp. 63-70 